\title{
APRESENTAÇÃo
}

\section{Como criticam os que criticam?}

Para pensar a crítica de mídia, há incontáveis perguntas na busca de respostas que deem conta da complexidade e necessidade dessa tarefa. Podese perguntar sobre as naturezas da crítica de mídia, os lugares nos quais se encontra, quais sujeitos a praticam, que diferenças há entre análise e crítica de mídia, quais são as perspectivas teóricas que a orientam. A partir da variedade de indagações abrem-se as possibilidades, igualmente diversas, de se estudar a crítica de mídia em diferentes instâncias ou modalidades: a) na percepção de parâmetros, do "como fazer para criticar", observando a operacionalização do ofício do crítico e, quando no campo do jornalismo, prestando atenção às implicações éticas e estéticas da cobertura dos acontecimentos noticiados; b) no estudo das críticas de mídia que circulam pela própria mídia, feitas por aqueles especialistas reconhecidos como críticos, ou seja, que possuem saberes que o público não domina; c) na crítica de mídia como gênero textual, praticado pelos especialistas a partir de determinadas convenções reconhecidas pelo público, possibilitando a circulação em espaços já institucionalizados, como jornais, revistas, blogs, entre outros; d) nas experiências metacríticas, em termos de conteúdo e forma, das inovações estéticas e estilísticas veiculadas na própria mídia - que, ao propor um novo formato ou gênero, empreendem uma crítica àquilo estabelecido como padrão, realizando-a não como uma análise sobre a mídia, mas no próprio fazer midiático; e) nos modos de leitura e perfis do público de crítica de mídia; f) nas interações sociais de crítica, nas quais receptores criticam de maneira dispersa e informal materiais veiculados nas mídias, não apenas questionando fundamentos de sua produção mas, principalmente, 
marcando lutas identitárias e disputas por hegemonia e reconhecimento; g) no estudo das "teorias da crítica", teorizando sobre os modos de "como criticam os que criticam" e de "como fazer para criticar"; e h) na crítica de mídia noticiosa como recurso didático-pedagógico para ensino e formação de profissionais, como jornalistas, e o trabalho de formação de leitores críticos de produtos midiáticos.

Em pequeno simpósio promovido pelo grupo de pesquisa Crítica de Mídia e Práticas Culturais em setembro de 2017 na Universidade Federal de Santa Catarina (UFSC), alguns pesquisadores da área da comunicação se dedicaram a discutir questões em torno da seguinte pergunta: como criticam os que criticam? Dessa atividade resultaram textos, agora publicados como artigos no dossiê. As disposições de pesquisadoras e pesquisadores se complementavam pelo esforço de discutir diferentes perspectivas teóricas de crítica, pensar a crítica de instituições e processos midiáticos de modo mais geral, fazer o exercício de crítica de objetos midiáticos particulares - com destaque para os do campo do jornalismo - e debater objetos midiáticos que se mostram críticos em si mesmos. Para além de possíveis respostas sobre os modos de se fazer a crítica de mídia, esses estudos trazem novas perguntas e problemas.

O dossiê começa buscando desdobramentos teóricos abertos e atuais para a abordagem crítica. Em "Transformações e atualidade da teoria crítica", Vera Veiga França - da Universidade Federal de Minas Gerais (UFMG) - avalia o comprometimento da mídia com o interesse coletivo e a justiça social, recuperando importantes matrizes da teoria crítica e seus desdobramentos para os estudos da comunicação. José Luiz Aidar Prado - da Pontifícia Universidade Católica de São Paulo (PUC-SP) - examina, em "Crítica de mídia em perspectiva aberta", o tema da polarização pós-2013 no Brasil com base na questão dos afetos, situando a crítica a partir de distintas correntes teóricas. Em seu artigo, Rogério Christofoletti (UFSC) preocupa-se com a ética jornalística e a crítica de mídia em "Padrões de manipulação no jornalismo brasileiro: fake news e a crítica de Perseu Abramo 30 anos depois", sugerindo alguns avanços nas proposições do 
autor, especialmente em face dos fenômenos da pós-verdade e das chamadas fake news. Em "Acontecimento e problemas públicos: elementos para uma crítica de cobertura jornalística", Terezinha Silva (UFSC) analisa a cobertura que as revistas Veja e CartaCapital realizaram da delação de executivos da Odebrecht na operação Lava Jato, fazendo a crítica da cobertura jornalística na percepção do acontecimento.

A recuperação de dados advindos da publicação de conteúdo jornalístico em meios digitais enseja uma crítica de mídia extensiva e ampliada. Em "Análise crítica da cobertura da previsão do tempo em portais especializados", María Luisa Sánchez Calero (Universidad Complutense de Madrid) investiga tendências e posicionamentos da informação meteorológica em portais especializados. Em "Etnografia como abordagem teórico-metodológica em estudos de crítica de mídia", Lívia de Souza Vieira (UFSC) propõe a utilização da etnografia baseada na teoria ator-rede, de Bruno Latour, para os estudos de newsmaking.

Pensando a crítica de maneira estendida, nas abordagens possíveis entre a tomada artística e ficcional de diferentes narrativas, Thiago Venanzoni - da Universidade de São Paulo (USP) - analisa, em "Modos de narrar, formas de descrever: processos de (trans)crição de um corpo", três obras audiovisuais, recuperando descrições e narrações sobre corpos em disputa no campo político e suas formas de sociabilidade. Finalmente, em "Crítica de mídia a partir de experiências em web arte", Andrea Limberto recupera experiências da internet como ponto de partida para uma investigação sobre como o trabalho com recursos digitais tem informado criticamente os circuitos de produção midiática adotando, como estudo de caso, os trabalhos de Lucas Bambozzi e Fábio Fon.

Fechando o dossiê, trazemos os principais tópicos da comunicação feita no evento pelo crítico de cinema e tradutor José Geraldo Couto, que, a partir da ideia de "Crítica do juízo, juízo da crítica", discutiu questões como a relevância da crítica, a dimensão criativa e especializada da tarefa do crítico, as pressões do mercado, a proliferação de espaços novos de crítica na internet e a política tratada em aspectos cinematográficos. 
Temos, então, no dossiê desta edição tanto exercícios de crítica, naqueles trabalhos que tratam de objetos/práticas midiáticas, e de metacrítica, nos textos em perspectiva teórica e reflexiva. Eles se dispõem, cada um à sua maneira, a observar objetos concretos/empíricos (produtos, processos e discursos) efetivamente em circulação nas mídias, estudar algumas condições de produção e problematizar a finalidade política da crítica. Juntos, assumem a responsabilidade e a urgência de tomar a crítica de mídia como uma tarefa acadêmica.

Gislene Silva Universidade Federal de Santa Catarina junho 2018 